\title{
Weight Gain and Chemical Changes in Low Birthweight Infants After Change from Human Milk to Modified Cow's Milk
}

\author{
D. P. DAVIES, R. SAUNDERS, and O. P. GRAY \\ From the Department of Child Health, The Welsh National School of Medicine, University of Wales (Cardiff); \\ and the Department of Biochemistry, Llandough Hospital
}

Davies, D. P., Saunders, R., and Gray, O. P. (1972). Archives of Disease in Childhood, 47, 946. Weight gain and chemical changes in low birthweight infants after change from human milk to modified cow's milk. Weight gain and some biochemical changes were observed in 7 preterm infants of low birthweight when their diet was abruptly changed from one of human milk to a modified cow's milk formula.

There was a fall in the serum calcium and a rise in the inorganic phosphate levels in the week after the changeover. Serum sodium was raised after two days, with a fall occurring over the following 5 days. Blood urea rose throughout the 7-day period. Accompanying these biochemical changes there was an acceleration in weight gain, and in 5 infants this was associated with peripheral oedema. In the second week after the changeover there was a deceleration in weight gain accompanied by loss of the oedema.

Immaturity of certain homeostatic mechanisms required to cope with the higher protein and electrolyte content of the modified cow's milk accounts for these observations. A more gradual dietary changeover, therefore, seems advisable.

The milk of choice for infants of low birthweight is human breast milk. Because of its limited supply, however, the majority of these infants at some stage, usually dependent upon their maturity and progress, will be changed to a modified cow's milk formula. The ease with which most of these infants adapt to this transition at such an early age is remarkable, having in mind the marked differences that exist between these milks. We have, nevertheless, been surprised to find few studies of the effects on the infant of this dietary change, even more so since careful observation during this changeover period might provide a clearer understanding of certain regulatory mechanisms necessary for a smooth adaptation to an extrauterine life.

This present study in a group of low birthweight infants describes some clinical and chemical changes that occur when the diet is abruptly changed from human milk to one of a modified cow's milk formula.

Received 10 April 1972.

\section{Clinical Material and Methods}

Seven preterm, low birthweight infants who were admitted to the Cardiff Maternity Hospital Special Care Unit were studied. The infants had all been fed human milk before being abruptly changed to an undiluted modified reduced-cream cow's milk formula, Ostermilk Number One (Glaxo). Table I compares

\section{TABLE I}

Protein and Major Electrolyte Composition of Mature Human Milk and Ostermilk Number One

\begin{tabular}{l|c|c}
\hline \multicolumn{1}{c|}{ Nutrient } & $\begin{array}{c}\text { Mature } \\
\text { Breast Milk }\end{array}$ & $\begin{array}{c}\text { Ostermilk } \\
\text { Number Onet }\end{array}$ \\
\hline Protein $(\mathrm{g} / 100 \mathrm{ml})$ & $1 \cdot 1$ & $2 \cdot 7$ \\
Sodium $(\mathrm{mg} / 100 \mathrm{ml})$ & $16 \cdot 1$ & $42 \cdot 1$ \\
Potassium $(\mathrm{mg} / 100 \mathrm{ml})$ & $50 \cdot 7$ & $132 \cdot 4$ \\
Chloride $(\mathrm{mg} / 100 \mathrm{ml})$ & $38 \cdot 5$ & $81 \cdot 9$ \\
Calcium $(\mathrm{mg} / 100 \mathrm{ml})$ & $34 \cdot 0$ & $93 \cdot 9$ \\
Phosphate $(\mathrm{mg} / 100 \mathrm{ml})$ & $14 \cdot 0$ & $74 \cdot 2$ \\
Ca $: \mathrm{PO}_{4}$ & $2 \cdot 4: 1$ & $1 \cdot 3: 1$ \\
\hline
\end{tabular}

$\star$ Taken from Fomon (1967).

†Manufacturer's data. 
the composition of human milk with the artificial milk. The time of changeover was determined by an experienced member of the nursing staff and depended upon (a) the progress of the infants and (b) the availability of the milk. The birthweight and gestational age at birth together with the day of changeover for each infant is given in Table II.

TABLE II

Details of 7 Infants Included in Study

\begin{tabular}{c|c|c|c}
\hline Infant & $\begin{array}{c}\text { Birthweight } \\
(\mathrm{g})\end{array}$ & $\begin{array}{c}\text { Gestational } \\
\text { Age at Birth } \\
\text { (wk) }\end{array}$ & $\begin{array}{c}\text { Day } \\
\text { of } \\
\text { Changeover }\end{array}$ \\
\hline 1 & 1740 & 34 & 21 \\
2 & 1200 & 30 & 50 \\
3 & 1870 & 35 & 22 \\
4 & 1000 & 32 & 30 \\
5 & 1550 & 33 & 24 \\
6 & 1490 & 31 & 25 \\
7 & 1710 & 33 & 21 \\
\hline Mean & 1510 & 32 & 28 \\
\hline
\end{tabular}

Before the changeover the infants were weighed twice weekly: afterwards they were weighed daily for two weeks. Capillary blood was obtained from a warmed heel-prick. The samples were centrifuged immediately after collection, and the serum was separated and stored at $-20^{\circ} \mathrm{C}$. Four specimens were obtained from each infant. The first was one hour before the first Ostermilk feed (Day 0), and then 1, 2, and 7 days later. On all occasions blood was taken at the same time of day ( 1400 hours), one hour before feeding. Serum sodium was estimated by flame photometry: serum calcium by the fluorimetric method of Lewin, Wills, and Baron (1969): serum inorganic phosphate by a micromodification of the stannous chloride reduction method (R. A. Saunders and D. G. Gibbs, personal communication, 1972) and blood urea by the Bertholet reaction. All clinical observations on the infants were made by one observer (D.P.D.).

\section{Results}

Weight gain. There was a considerable increase in the mean daily weight gain during the first week after the changeover, with the daily increment increasing from $19 \mathrm{~g}$ in the previous week to $40 \mathrm{~g}$ (Table III). Oedema of the feet

\section{TABLE III}

Mean Daily Weight Gain and Milk Intake in 7 Low Birthweight Infants Before and After Dietary Changeover from Human to Modified Cow's Milk Formula

\begin{tabular}{l|c|c|c}
\hline \multicolumn{1}{c|}{ Period } & $\begin{array}{c}\text { No. } \\
\text { of } \\
\text { Infants }\end{array}$ & $\begin{array}{c}\text { Mean } \\
\text { Daily } \\
\text { Weight } \\
\text { Gain } \\
\text { (g/day) }\end{array}$ & $\begin{array}{c}\text { Mean } \\
\text { Daily } \\
\text { Milk } \\
\text { Intake } \\
\text { (ml/kg) }\end{array}$ \\
\hline 1 week before changeover & 7 & 19 & 230 \\
1st week after changeover & 7 & 40 & 220 \\
2nd week after changeover & 4 & 22 & 230 \\
\hline
\end{tabular}

was observed to accompany this weight gain in five infants and in three of these there was also oedema of the eyelids. Four infants with peripheral oedema remained in hospital a further week. In these there was a fall in the mean daily weight gain to $22 \mathrm{~g}$ and this was accompanied by a loss of the oedema.

Changes in sodium and blood urea (Table IV). The mean value for serum sodium rose significantly $(P<0.05)$ from 141 to $147 \mathrm{mEq} / \mathrm{l}$. in the initial 48 hours after changeover. There was a fall to $144 \mathrm{mEq} / \mathrm{l}$. during the next 5 days. The blood urea rose throughout the 7-day period from 24 to $39 \mathrm{mg} / 100 \mathrm{ml}$.

Changes in calcium and inorganic phosphate (Table IV). There was a significant fall in the serum calcium from a mean value of $9.5 \mathrm{mg} / 100 \mathrm{ml}$ before changeover to $8.4 \mathrm{mg} / 100 \mathrm{ml} 7$ days later. At the same time the serum inorganic phosphate rose significantly from $5 \cdot 6$ to $7 \cdot 1 \mathrm{mg} / 100 \mathrm{ml}$ ( $P<0.01$ in both instances).

TABLE IV

Mean Values For Serum Sodium, Calcium, Inorganic Phosphate, and Blood Urea

\begin{tabular}{|c|c|c|c|c|c|}
\hline \multirow{2}{*}{ Determination } & \multicolumn{4}{|c|}{ Day of Investigation * } & \multirow{2}{*}{$\begin{array}{c}\text { Standard Error of } \\
\text { Difference Between } \\
\text { Any Two Means }\end{array}$} \\
\hline & 0 & 1 & 2 & 7 & \\
\hline $\begin{array}{l}\text { Sodium }(\mathrm{mEq} / 1 .) \\
\text { Calcium }(\mathrm{mg} / 100 \mathrm{ml}) \\
\text { Inorganic phosphate }(\mathrm{mg} / 100 \mathrm{ml}) \\
\text { Urea }(\mathrm{mg} / 100 \mathrm{ml})\end{array}$ & $\begin{array}{c}141 \\
9 \cdot 5 \\
5 \cdot 6 \\
24\end{array}$ & $\begin{array}{l}144 \\
9 \cdot 2 \\
6 \cdot 1 \\
29\end{array}$ & $\begin{array}{l}147 \\
8 \cdot 7 \\
6 \cdot 5 \\
35\end{array}$ & $\begin{array}{c}144 \\
8 \cdot 4 \\
7 \cdot 1 \\
39\end{array}$ & $\begin{array}{l}0.95(P<0.05) \\
0.38(P<0.01) \\
0.29(P<0.01) \\
2.07(P<0.05)\end{array}$ \\
\hline
\end{tabular}

$\star_{0}=1$ hour before changeover from human to cow's milk.

1 = 1 day after changeover from human to cow's milk.

2 - 2 days after changeover from human to cow's milk.

$7=7$ days after changeover from human to cow's milk. 


\section{Discussion}

Weight gain. It is likely that the accelerated weight gain in the week after the changeover was due to fluid retention from the high solute load presented by the modified cow's milk formula, which is nearly three times that of human milk (Fomon, 1967). Gordon et al. (1937) observed oedema in some premature infants after an abrupt changeover from diets of human to cow's milk, and in these infants there was a definite lag in the renal excretion of the extra sodium provided by the cow's milk. This limited capacity to cope with the increased solute load of cow's milk is due probably to the low renal glomerular filtration rate of the premature infant (Edelmann and Spitzer, 1969), and obligatory water retention with a corresponding marked increase in weight gain results.

The significant rise in serum sodium from 141 to $147 \mathrm{mEq} / \mathrm{l}$. during the initial 48 hours after the changeover in our infants supports this hypothesis, with the gradual fall during the next 5 days probably representing a dilution consequent upon expansion of the extravascular space. The continuing rise in blood urea nitrogen throughout the whole 7-day period is due probably to a combination of (a) the reduced urea clearance which exists in premature infants (Gordon, Harrison, and McNamara, 1942), and (b) the simple increase in dietary protein intake (Davidson et al., 1967).

It is interesting that of the 5 infants who showed an accelerated weight gain in the week after the changeover, the 4 who remained in hospital a further week showed a deceleration in weight gain to a daily increment of $22 \mathrm{~g}$. Since this was accompanied by a gradual disappearance of the peripheral oedema it seems reasonable to believe that the premature infant has a considerable capacity for renal adjustment to the increased solute load. The mechanism for this adjustment might lie in the renal control of sodium excretion since in the young piglet sodium loading has been shown to increase the fractional excretion of sodium by the renal tubule (Gruskin et al., 1970). A similar mechanism for adapting to an increased solute load might similarly exist in premature infants, with obligatory water loss accompanying the increased sodium excretion.

In the thriving premature infant four phases of growth in weight are observed (Gairdner and Pearson, 1971): an immediate postnatal weight loss; a curve running parallel to the fetal weight curve; a phase of acceleration usually maintained until the genetically appropriate weight centile is reached; and a final phase when the curve con- tinues along this same centile. Seen in the context of this description of early postnatal growth the importance of recognizing the phenomenon of a transient increase in weight velocity after a dietary changeover from human to cow's milk is evident, since in some premature infants the phase of acceleration might be the result of this dietary transition and merely reflect fluid retention. To consider such weight gain true growth is therefore misleading, emphasizing again the fallibility of weight gain as a parameter of growth in the neonatal period.

Changes in calcium and inorganic phosphate. One possible explanation for the significant fall in serum calcium and the increase in serum inorganic phosphate in the week after the dietary changeover is the increased phosphate load presented by the undiluted modified cow's milk, since this has previously been shown to be associated with hypocalcaemia and hyperphosphataemia in the newborn (Baum, Cooper, and Davies, 1968). However, since these infants had all been fed human milk, a further explanation might be offered which is derived from the animal studies of Rogers and Bergstrom (1971). By inducing a state of parathyroid unresponsiveness in the rat by feeding a diet low in phosphate (with a raised calcium to phosphate ratio), these authors were able to show the importance of early parathyroid stimulation for the maturation of calcium homeostatic mechanisms in the neonatal period, since both hypocalcaemia and hyperphosphataemia resulted when these rats were challenged with a high phosphate load. Partial amelioration occurred when they were given parathyroid hormone so that the phenomenon was called 'diet induced hypoparathyroidism'.

A similar mechanism might be operating in our infants when their milk diet is changed. Stimulation of the fetal parathyroid in utero is minimal and its calcium and phosphate regulation depends on maternal and placental factors (Rogers and Bergstrom, 1971). By maintaining premature infants on human milk with its low phosphate and high calcium to phosphate ratio, this state of relative hypoparathyroidism might be allowed to persist, with a resulting inability to respond to the increased phosphate load of the cow's milk. A fall in the serum calcium and an increase in the organic phosphorus levels would then result.

None of the infants developed neuromuscular symptoms with the fall in calcium, but this is hardly surprising since at no time did the calcium levels fall into the recognized hypocalcaemic range$<7.5 \mathrm{mg} / 100 \mathrm{ml}$ (Keen, 1969). It must, however, be noted that the daily milk intake in the week 
after changeover differed very little from that of the previous week, $220 \mathrm{ml} / \mathrm{kg}$ compared with 230 $\mathrm{ml} / \mathrm{kg}$ (Table III). Were a greater volume to have been given immediately after the changeover, the even greater phosphate load might then have resulted in the serum calcium falling to true hypocalcaemic levels.

\section{Conclusion}

This study has unmasked some of the problems the premature infant has in adapting to the higher protein and electrolyte content of cow's milk after being fed human milk for a considerable period. An awareness of these problems is important, since such an abrupt change renders these infants vulnerable to not inconsiderable electrolyte disturbances. This vulnerability could possibly have been reduced in this instance if a more gradual transition had been allowed, with the cow's milk formula being diluted with breast milk over a period of a week so as to allow such homeostatic mechanisms as are necessary to evolve in a more physiological manner. This gradual method of changeover has been adopted in many Special Care Nurseries, though the reasons given for doing so have often been vague and difficult to account for. The results of this present study would nevertheless suggest a gradual changeover to be correct.

We express our gratitude to the Nursing Staff of the Special Care Unit, Cardiff Maternity Hospital, for their help, and to Dr. P. Ellwood and Mrs. J. Hughes for statistical advice.

\section{REFBRENCES}

Baum, D., Cooper, L., and Davies, P. A. (1968). Hypocalcaemic fits in neonates. Lancet, $1,598$.

Davidson, M., Levine, S. Z., Bauer, C. H., and Dann, M. (1967). Feeding studies in low-birthweight infants. I. Relationships of dietary protein, fat, and electrolyte to rates of weight gain, clinical courses, and serum chemical concentrations. fournal of Pediatrics, 70, 695.

Edelmann, C. M., Jr., and Spitzer, A. (1969). The maturing kidney. Fournal of Pediatrics, 75, 509.

Fomon, S. J. (1967). Infant Nutrition, p. 195. Saunders, Philadelphia and London.

Gairdner, D., and Pearson, J. (1971). A growth chart for premature and other infants. Archives of Disease in Childhood, 46, 783.

Gordon, H. H., Harrison, H. E., and McNamara, H. (1942). The urea clearance of young premature and full term infants. fournal of Clinical Investigation, 21, 499.

Gordon, H. H., Levine, S. Z., Wheatley, M. A., and Marples, E. (1937). Respiratory metabolism in infancy and in childhood. $\mathrm{XX}$. The nitrogen metabolism in premature infants-comparative studies of human milk and cow's milk. American fournal of Diseases of Children, 54, 1030.

Gruskin, A. B., Oetliker, O. H., Jr., Wolfish, N. M., Gootman, N. L., Bernstein, J., and Edelmann, C. M., Jr. (1970). Effects of angiography on renal function and histology in infants and piglets. Fournal of Pediatrics, 76, 41.

Keen, J. H. (1969). Significance of hypocalcaemia in neonatal convulsions. Archives of Disease in Childhood, 44, 356.

Lewin, M. R., Wills, M. R., and Baron, D. N. (1969). Ultramicrofluorimetric determination of calcium in plasma. Fournal of Clinical Pathology, 22, 222.

Rogers, M. C., and Bergstrom, W. H. (1971). Diet-induced hypoparathyroidism: a model for neonatal tetany. Pediatrics, 47, 207.

Correspondence to Dr. D. P. Davies, Department of Child Health, Cardiff Royal Infirmary, Cardiff CF2 1SZ. 